Accepted for publication by Critical Inquiry on 11/09/2015 -

http://www.journals.uchicago.edu/toc/ci/current

BEFORE AND ABOVE

Spinoza and symbolic necessity

\title{
Catherine Malabou
}

In Spinoza, God is without a name and without a shape. His essence is the very form of the necessity of nature, the infinite regularity, actuality and rationality of what there is. Nothing good, nothing bad in this. All representations of God as a legislator, a creator or a father, endowed with intentions, are only human projections produced by an inadequate understanding of what a cause is. A true cause is never separated from its effect, but is immanent to it, which means that it remains within it. As cause of himself, that is of nature, God is nothing but his own effectuation, and in that sense, he cannot be said transcendent, that is external, to what he produces.

Are the readings of Spinoza that characterize him only as a thinker of "immanence" and/or "self-regulation" totally fair though?

Do they do justice to the major issue of the origin of the sacred as developped in the Theological-Political Treatise ? Where does sacredness come from for Spinoza ? Can it be reduced to a sheer error or illusion, a temporary hole in the tissue of immanence, or does it open a specific space in immanence that remains to be explored ? What exactly are the relationships between necessity and faith, between truth and its irreducible symbolic dimension? And what does "symbolic" means there where God is impersonal ? Following Spinoza scriptural hermeneutics, and discussing it also with thinkers like Levinas, we will develop a new approach to Spinoza's concept of revelation, pertaining to his vision of the sacred as an economy of signs without a referent.

In doing so, we would like to show that Spinoza's critique of religious dogmatism or fanatism is not to be confused with the dismissal of the sacred, it is on the contrary propedeutical to the philosophical delineation of sacredness. 


\section{The Space of Revelation}

The most famous of all "immanentist" readings of Spinoza is undoubtedly that of Gilles Deleuze, who calls Spinoza the "prince of immanence." Very early, in Expressionism in Philosophy, Deleuze insists upon the difference between "immanere" and "emanare," showing that the God of Spinoza has no eminence, does not hold himself "above" the creatures, but is horizontal and "stays" with what it "expresses." ${ }^{1}(E P, 40-41)$ "Expression" is presented as the logical correlate to immanence, that is, to a specific mode of causation and production of truth: a causation and production that "produce while remaining in themselves" (EP 171). Immanent causation implies that the effect remains within the cause with no external help. This type of "remaining within" precisely constitutes the meaning of expression. We then have to understand that "expression" is a mode of outing that never goes outside of itself, despite what the prefix "ex" might let us think - it is a modality of production that never separates itself from what it produces, a remanent externality so to speak. Therefore, "expression" is the logos of immanence, its privileged "Word (parole)" as well as its ontological actuality. Deleuze underscores the "logical links" that tie immanence and expression together several times (see EP Ch. 11).

It goes without saying that Deleuze's reading of Spinoza is one of the most profound of all. Nevertheless, the main issue raised by Deleuze's understanding and privileging of "expression" is the rigid - dogmatic even - distinction it implies (or creates) between "expression" and "impression," that is between rationality and the supposedly "other Word," the "other knowledge" and other production of meaning at work in Spinoza: revelation. Expression and revelation coexist in Spinoza, according to Deleuze, as two antagonistic and definitely unequal regimes of representation, philosophy and religion. The former is adequate, the latter is inadequate. The first one (expression, that proceeds "more geometrico" and is at work in the Ethics), functions as a paradoxical non-linguistic language, whereas the second (revelation) is entirely based on signs that "impress" the prophets' souls, consequently also the people's mind. The former does not properly signify, the latter does not properly express. "Spinoza therefore sets apart two domains which were always confused in earlier traditions: that of expression and of the expressive knowledge that alone is adequate; and that of signs and of knowledge by signs" (EP 181). The difference between two types of relationships - 
between "expression and the expressed" and of "sign and signified" (EP 57) - are of deeply dissimilar kind. The way in which expression expresses again defines immanent causation. The expressed, as the result or product of expression, is never outside expression, it never separates itself from it. On the contrary, a sign always "stands for" something else than itself, refers to something external, and that is why knowledge by signs makes us think that God himself is outside nature, occupies the transcendent position of a reference. Therefore, "revelation is not an expression, but a cultivation of the inexpressible, a confused and relative knowledge through which we lend God determinations analogous to our own (Understanding, Will), only to rescue God's superiority through his eminence in all genera (the supereminent One, etc.). [...] The opposition of expressions and signs is one of the fundamental principles of Spinozism" (EP 181-82). Revelation then appears as an inadequate version of immanence, the one "man" creates.

Why is the distinction between "expression" and "impression" problematic? Why can't we adhere to Deleuze's interpretation of the distinction between reason and revelation? Because in reading Spinoza as he does, Deleuze reduces to nothing the necessity of revelation, which in principle is not distinct from the necessity developed in the Ethics while presenting itself differently. In reducing revelation to a human mode of understanding, in not questioning revelation at the level of God himself, Deleuze fails to address a question that does not appear in the Ethics and that I would like to characterize here as the origin of the symbolic, coextensive with the origin and determination of the sacred. The way in which God "signifies" cannot be a pure fantasy of the human mind, it designates a certain regime of ideality by which ideas themselves appear as symbolically showcased.

To locate the origin of the symbolic (and not that of truth) is the immense task undertaken by the Theological-Political Treatise, and constitutes an essential dimension of the altogether political, philosophical, ethical nature of Spinoza's Biblical hermeneutics. I believe that Spinoza's approach to hermeneutics, as developed in the Treatise, opens a space that is precisely neither that of immanence, nor that of transcendence, and as such makes the distinction between impression and expression explode. Such a space is what I intend to circumscribe here.

To do so, I won't limit myself to a reading of Deleuze, but will also turn toward Levinas, and this about the same questions. According to an apparently opposed perspective, Levinas affirms that Spinoza's approach to revelation, as well as his critical method of interpretation of the Scripture, is not immanent enough. ${ }^{1}$ For that very reason, it paradoxically misses the true dimension of transcendence that constitutes the very essence of revelation. 
Levinas never understands the role of revelation in Spinoza as limited to inadequate knowledge. Contrarily to Deleuze, he challenges what he sees as a mistreatment of the signs of and in revelation in Spinoza, a dismissal of signification as such. He reproaches Spinoza for not having gone deep enough in "what is signified in the signifier [la signifiance du signifiant]" of revelation ( $B V 110)$. As if there were too little signs in Spinoza's "knowledge by signs"! If Spinoza had been consistent with himself, he would have been able to better show that "knowledge by signs" responded to an essential and necessary dimension of God, not to a weakness of the human mind, and he would have elaborated the accurate hermeneutical method able to bring to light such a necessity. Instead of setting up a method that constantly demonstrates that the Bible needs help, he should have discovered a principle of hermeneutical self-regulation at work in it, a self-regulation that constantly both produces and maintains its "significative signification." If Spinoza had been a genuine Spinozist, reason and faith, even if fundamentally separated, would have been nevertheless clearly deduced from the same, even if twofold, principle: self-regulation. Geometrical self-regulation in/as the rational and hermeneutical self-regulation in/as the religious. As we will see, for Levinas, hermeneutical self-regulation is the immanent meaning of transcendence.

It is true that there is no hermeneutical self-regulation in Spinoza. Yet, as I intend to demonstrate, such an absence certainly does not prevent him from developing a genuine concept of the symbolic and the "significative signification".

Following the logic of the two opposite paths that circle and strangle Spinoza within the bounds of either strict or loose immanence, I will show how Spinoza's hermeneutics escapes them by determining the symbolic, and consequently also situating the sacred as an irreducible dimension of divine necessity. This determination both Deleuze and Levinas fail to perceive and apprehend as it deserves to be. To acknowledge such a symbolic space in Spinoza is indispensable to both his understanding of hermeneutics and of philosophy.

\section{Revelation and Necessity}

In Expressionism in Philosophy, Deleuze never presents revelation as what it first and foremost is, that is a historical event, or more precisely a necessary historical event, or fact. For Spinoza, revelation absolutely had to happen. ${ }^{2}$

I find strange that so few Spinoza readers interrogate the type of necessity revelation is endowed with, as well as the relationship between such a necessity and the one presented as 
the nature of God in the Ethics. When Deleuze understands revelation as a human "cultivation," he goes too fast. It is true that revelation is analysed in many passages of the Treatise as a way to touch the multitude by other means than that of reason, which implies a mode of communication that essentially speaks to imagination and fantasy. I will of course have to come to this later. What I want to suggest at the moment is that the assimilation between revelation and the specific mode of communication which it partly is cannot obliterate that revelation is essentially, that is ontologically, a fact.

In a certain sense, revelation cannot be anything else but a fact, and Spinozist concept of revelation is no exception to that. In one of the very important texts of Beyond the Verse, "Revelation in the Jewish Tradition," Levinas very rightly declares: "I think that [the] fundamental question [...] concerns less the content ascribed to revelation than the actual fact - metaphysical one - called the Revelation. This fact is also the first most important content revealed in any revelation" ( $B V 129)$. What revelation first and foremost reveals is revelation itself, that is, its own fact. Revelation reveals its own factuality - a factuality that is both, all at once, historical and ontological. We don't see how "the ontological status or regime of the Revelation" ( $B V 131)$, as Levinas beautifully puts it, could not have been a question for Spinoza!

Spinoza clearly aknowledges the factuality of revelation, which is a first reason not to assimilate it to a "human cultivation". A second major reason why the process of revelation cannot be limited to human inadequate knowledge appears when Spinoza explains, in the Treatise, that the communication between God and the Christ was rational and adequate. To play with Deleuze's concepts, it was certainly not an "impression" but precisely an "expression"! The fact, as well as the content of revelation, appeared as adequately, that is, entirely rationally understandable, to Christ. "If Moses spoke with God face to face as a man speaks with his friends (i.e. by the mean of two bodies) Christ communed with God mind to mind" (TTP 119). ${ }^{3}$ Further: "Inasuch as God revealed Himself to Christ, or to Christ's mind immediately, and not as to the prophets through words and symbols, we must needs suppose that Christ perceived truly what was revealed, in other words, He understood it, for a matter is understood when it is perceived simply by the mind without words or symbols. Christ, then, perceived (truly and adequately) what was revealed" (TTP 64). Revelation and adequate knowledge are then originally and obviously not opposed.

Of course, we have to immediately admit that the necessity of revelation, when not seen only from the point of view of the communication between God and Christ, remains for the most part inaccessible to our natural light. We may be forced, because of the limits of our 
nature, to perceive the necessity of revelation from the sole pragmatic point of view of its utility. In his remarkable book Le Dieu de Spinoza, Victor Brochard, who precisely insists on revelation being a "historical fact," assumes that Spinoza identifies the necessity of revelation with its pragmatic function. When Spinoza says: "I wish to emphasise in express terms $[. .$.$] the importance and necessity of the role I assign to Scripture, or Revelation" (TTP$ 172), he supposedly understands "necessity" as "utility". For Spinoza, the utility of revelation consists in the link it establishes between salvation and obedience and salvation, and such a link, as it appears in several passages of the Treatise, cannot be rationally deduced properly speaking. In a certain sense, its foundation is beyond our philosophical reach. In Chapter 15, Spinoza declares: “[...] I maintain absolutely that this fundamental dogm of theology cannot be investigated by the natural light of reason, or at least that nobody has been successful in proving it, and that therefore it was essential that there should be revelation." (TTP 169-170) The "necessity" of revelation here only pertains to the "moral certainty" it confers (170).

Yet, for Spinoza, the fact that the necessity of revelation remains indemonstrable, that knowledge and faith are totally independent from one another, that moral certainty and philosophical truth are of different nature, and that Scripture has no metaphysical meaning (as so powerfully affirmed in Chapter 7), cannot erase the ideality of revelation, its originary adequacy once again at the level of God himself and his "mind to mind communication" with Christ. We may ask, then, what constitutes the threshold between such an ontological divine ideality and the abundance of signs, fictions, images, illusions that accompany revelation for men, fashion the prophetic mind and determine the way in which the multitude immediately receive the concept of God. The determination of such a threshold is precisely the point on which Deleuze glides too quickly.

This threshold, the very in-between philosophy and revelation, is brought to light, as we will see, with the elaboration of the Biblical hermeneutical - "historico-critical" - method. Spinoza's method of interpretation is the space of negotiation between revelation as divine necessity and revelation as human reception of such a necessity.

\section{God's "adaptation" to the mind of the multitude}

It is clear for Spinoza that the Scripture commands obedience and love of one's neighbour in a form that is not that of adequate knowledge or rationality. What is understood adequately by Christ is perceived by the multitude in the inadequate form of a legislator's 
commandment or law. Adam, the first human being, bears witness to such a perception: "Adam perceived this revelation not as an eternal and necessary truth but as a law, that is an enactment from which good or ill consequence would ensue not from the intrinsic nature of the deed performed but only from the will and absolute power of some ruler. Therefore that revelation, solely in relation to Adam and solely because of the limitations of his knowledge, was a law, and God was a kind of lawgiver or ruler." (TTP 53).

It is then very easy to conclude that Adam's example - his lack of knowledge of what a law is, his incapacity to mentally access necessity - is paradigmatic of the people in general, and to state that the majority of people have a weak mind. Brochard comments:

The great majority of men are not able to reach true knowledge, their spirit is too weak, the passions that render them dependent upon the rest of nature have too great an influence on their soul to allow them to situate themselves in the right perspective and perceive the genuine and true chain of natural causes. This implies either to abandon them to their fate or to use a detour [moyen détourné] to lead them to the right result. That is why God revealed religion to them. Religion presents the truths that necessarily follow from the essence of God as decrees written by a legislator or a king. It replaces intelligence by obedience, love by submission and piety; but in both cases, it is the same truth that is taught in two different forms. Moral law is the equivalent of natural law, it is natural law expressed in an other language, adapted to human weakness, reachable by those who don't have the leisure or the means to attain true knowledge. ${ }^{5}$

It is true that if Christ, who adequately perceived the content of revelation, "ever proclaimed these things as law, he did so because of the people's ignorance and obstinacy" (TTP 54). Again, the multitude perceives God as a legislator, a king endowed with free will, mystery and power. ${ }^{6}$ Further: "For since we cannot perceive by the natural light that simple obedience is a way to salvation, and since only revelation teaches us that this comes about by God's singular grace which we cannot attain by reason, it follows that Scripture has brought very great comfort to mankind. For all men without exception are capable of obedience, while there are only a few - in proportion to the whole of humanity - who acquire a virtuous disposition under the guidance of reason alone. Thus, did we not had the testimony of Scripture, the salvation of nearly all men would be in doubt" (TTP172).

The threshold we are looking for then compels us to determine the status of the accommodation or adaptation of revelation to the opinions of mankind. ${ }^{7}$ Where does such an “accommodation" come from? God or men? 
We are touching here the critical point. Let's examine the two axes of such an alternative. 1) Let's admit that the "accommodation" or "adaptation" is a production of the human mind. Are we to understand then that Spinoza, one of the greatest defenders of democracy and free speech, systematically assigns revelation - understood as a naive, confuse and anthropomorphic mode of transmission - to the multitude understood as a crowd of ignorants and non-rational spirits? 2) If such an "accommodation" or "adaptation" rather pertains to the nature of God, are we then to understand that if God has "adapted" his revelation to human mind, it is because he was also a personal God, endowed with free will? Are we to understand that the God of Spinoza is not only that, without a name, of the Ethics, but in some respect also an intentional God? Aren't we force to admit that he wanted to reveal himself?

Such an alternative in reality is a false one, and only engages the reading of Spinoza in a series of aporias.

First, Deleuze's. Of course Deleuze never says that the multitude is a bunch of ignorants and weak-minded individuals. Nevertheless, and definitely, revelation, as we saw, is for him assigned to the first kind of knowledge, and assimilated, again, with "a cultivation of the inexpressible." Deleuze adds: "Whatever its sorts, knowledge through signs is never expressive, and remains of the first kind. Indication is not an expression, but a confused state of involvement in which an idea remains powerless to explain itself or to express its own cause. An imperative sign is not an expression, but a confuse impression which leads us to believe that the true expressions of God, the laws of nature, are so many commandments" (EP 181). Further, the imperative signs of moral laws and religious revelation are "decisively rejected as inadequate" (EP 330).

Such an understanding is highly problematic. First, and once again, because it fails to explain the necessity of revelation. Revelation is not a prophetic invention but, again, first and foremost, a divine necessity, otherwise it wouldn't have happened as what it is, an irreducible fact. Second, because inadequate knowledge can by its essence be superseded and transformed into superior forms of knowledge, whereas the content of revelation (moral certainty, obedience) is alien to knowledge and cannot for that very reason get rationalized. The intellectual love of God, as presented in the Ethics, is not exactly a "sublation" (Deleuze would have hated the term, but he forces me to use it here) of the religious form of love given and revealed to the common people. If faith and philosophy are separated, then it means that faith is not a form of knowledge, be it inadequate. In his demonstration, Deleuze conflates two inassimilable levels in identifying revelation with a first kind of knowledge. 
It then seems that we can only: 1) Either dismiss the ontological and epistemological value of revelation by rejecting it "into the inadequate" as Deleuze illegitimately does; 2) Or acknowledge this value but then be forced at the same time to admit the intervention of a personal God.

Second, Brochard's. This is the conclusion to which Victor Brochard is led to. He is careful to state that religion is not an inadequate form of the human mind: "Men have not invented religion, it is God himself who revealed it to them." ${ }^{8}$ God himself so to speak has altered his own truth: "Men have not, out of impotency or impiety, altered the truth, it is God himself who did it; or it is possible at least that he adapted and proportioned it to human impotency and weakness. If such is the case, we are forced to admit that this same God that philosophy perceives, is not only the thinking and extended substance that reason conceives. There must be intentions, a benevolent will in him. [...] In the last instance, the God of Spinoza is a personal God." 9

It then seems that the necessity of revelation - in order to be acknowledged as an originally divine, and not human, phenomenon - had to proceed from divine generosity, which of course is a problematic reading of Spinozism that introduces a strong Christian dimension in it, along with a philosophical impossibility.

This conclusion leads us to a third aporetic approach to Spinoza. After the first one (Spinoza as a contemptor of the multitude's mind), after the second one (Spinoza as a Christian thinker), we have now to follow the third one: Spinoza as an unfaithful Jew.

Third, Levinas'. The supposed "Christian" dimension of Spinoza is the reason that allows Levinas to speak of Spinoza's "betrayal” of Judaism.

In "The Spinoza Case," a text written about the rehabilitation of Spinoza in Israel by Ben Gourion in 1953, Levinas states: "We entirely agree with the opinion our late lamented and admirable friend Jacob Gordin: Spinoza was guilty of betrayal. Within the history of ideas, he subordinated the truth of Judaism to the revelation of the New Testament. The latter is of course suppressed by the intellectual love of God, but Western being involves the Christian experience, even if it is only a stage" ( $D F$ 108). Further: "Our feeling for Christianity is wholehearted, but it remains one of friendship and fraternity. It cannot become paternal. We cannot recognize a child that is not ours" ( $D F$ 109). We cannot, then, fully recognize Spinoza as one of us, as one of our sons, Levinas says. I will come back to the argument of the supposed Christianisation of Judaism by Spinoza. What I want to insist upon at the moment is that Levinas, far from dismissing the argument of a personal God in Spinoza, 
on the contrary argues that Spinoza's personal God is not the one it should have been, that is, the one of the Thora, to the extent that he can definitely be identified with the Christian one.

Levinas agrees with Brochard on one point: revelation is conceivable only as a relationship with a personal God. The problem is to specify what exactly a "personal" God means in Judaism. It certainly does not mean that God "is a person", as it does in Christianity!

The very specific meaning of the "personal" in Judaism is explained in "Revelation in the Jewish Tradition." Levinas follows Spinoza when he affirms that revelation "is from the outset [...] commandment, and piety is obedience to it" (BV 132). Nevertheless, the "message" of revelation does ascertain the immediate personal presence of God. It "requires [...] a personal God: Is a God not personal before all characteristics?" (BV 164).

Here though, "personal" certainly does not mean what Brochard supposes it does. A new meaning of "personal" appears at that point, a non-Chritian meaning, a meaning that Spinoza would have failed to aknowledge. Levinas declares: God is personal in the sense that he "appeals to persons" ( $B V 134)$, appeals to each person in its historical uniqueness. Here is the specifically Jewish signification of the "personal." "Personal" God does not mean that God is a person but that God is met in person, that is, in the person, through it. "Man is the place through which [Revelation] passes" (BV 145). In Judaism, each person is a reader and an interpreter of the message, each person is able to "extract" the meaning from the letters, as if the letters were "the folded-back wings of the spirit" (BV 132).

Profoundly missing the authentic spiritual dimension of both the form and content of the Thora, privileging the New over the Old Testament, Spinoza would have remained alien to this very particular signification of the "personal," and would then have failed to understand (was it because he was ill-taught in Jewish studies?) ${ }^{10}$ that the "invitation to seek and decipher, to Midrach, already constitutes the reader's participation in the Revelation, in Scripture" (BV 133).

We can now clearly formulate what we called earlier the hermeneutical self-regulation principle that, for Levinas, lies at the very heart of the Thora, is the Thora itself, and would have escaped Spinoza: each singularity ("person") has an immediate ("automatic" one might say) access to the universal. Everyone is a reader. Everyone is an interpreter. No need to invoke signs, fantasies, fictions or illusions. Every approach to the text is just, true, acceptable. The multitude's approach is automatically hermeneutically justified. "The Revelation as calling to the unique within me is the significance particular to the signifying of the Revelation. It is as if the multiplicity of persons - is not this the very meaning of the personal? - were the condition for the plenitude of 'absolute' truth; as if every person, 
through its uniqueness, of the revelation of a unique aspect of truth, and some of its points would never have been revealed if some people had been absent from mankind" ( $B V 133)$. In "Spinoza's Background" - another chapter of Beyond the Verse - Levinas has this beautiful statement: "Something would remain unrevealed in the Revelation if a single soul in its particularity were to be missing from the exegesis" ( $B V 171)$.

In this common/personal participation to the reading and interpretation resides the authentic ethical mission of Judaism: "my very uniqueness lies in the responsibility for the other man" (BV 142). But also its democratic (revolutionary even) principle : "The adventure of the Spirit [...] takes place on earth among men. The trauma experienced as a slave in the land of Egypt constitutes my humanity itself. This immediately brings me closer all the problems of the damned of earth, of all who are persecuted, as if in my suffering as a slave I prayed in a prayer that was not yet oration, as if the love of the stranger were already the reply given to me though my heart of flesh" (BV 142). No need, again, to argue that the people's capacity to interpret the text necessarily proceeds from an inadequate kind of knowledge. The Talmudic scholars are certainly there to guide these interpretations. In essence, such interpretations are nevertheless irreducible to sheer "subjective impressions."11

The Talmud, which opens the space of an infinite discussion of the Thora, legitimates all readings as long as they are personal. When the reading is an authentically personal one, it cannot be arbitrary! Apparent paradox only! "This in no way means that in Jewish spirituality, the Revelation is left to the arbitrariness of subjective fantasies. [...] Fantasy is not the essence of the subjective" (BV 134-35).

What, then, is the "essence of the subjective"? We find a definition of the symbolic at that point. Levinas defines it as what exceeds the strict "signification" process: "The aimed of the signified by the signifier is not the only way to signify" ( $B V 110)$. "What is signified in the signifier [significance]," and is not reducible, once again, to the right coincidence between the signified and the signifier, as Deleuze claims, is precisely the symbolic dimension of signification in general.

If language was only "expressive" in the Deleuzian sense, if "meaning" in general were determined by the strict adequacy of signified to the signifier, and of the signifier to the referent, reading and understanding would only consist in silently and objectively receiving such an adequacy. Hermeneutics would not even have to exist, it would not be necessary. But such is not the case. The subjective "solicitation" of otherness in the text, the constant alterity of the text to itself enhanced by its interpretability force the reader to intervene. The "essence of the subjective" is the extasis of the identical. 
For Levinas, this extasis obviously comes from the "transcendence of the message" of Revelation ( $B V$ 131), the "rupture of immanence" it provokes ( $B V 144)$. Paradoxically, this "rupture" is not antagonistic with the self-regulative hermeneutical principle, it is on the contrary its very condition of possibility. The transcendence of the message is immanently regulated by the self-engendering movement of the symbolic dimension of the Thora, constituted by the living and constant dynamism of "personal" interpretations.

Again, Spinoza would have missed this immanent dimension of transcendence to the extent that he did not credit the Bible with a hermeneutical self-engendering and regulating dimension. In that sense, because of his rejection of transcendence, there is not enough immanence in Spinoza. "Spinoza will not have conferred a role in the production of meaning on the reader of the text, and - if one may put it this way - he will not have given a gift of prophecy to the act of hearing [à l'oreille]" (BV 173). He has missed "a meaning coming from behind the signs that are immediately given: a coming that seeks out a hermeneutic" ( $B V$ 173). If "to his credit, Spinoza did reserve for the Word of God a proper status outside opinion and 'adequate' ideas" ( $D F$ 117) - a status that Deleuze does not acknowledge - he nevertheless failed to bring to light the hermeneutical inexhaustible treasure of this Word. We will see that Spinoza's Christian betrayal is another name for this failure. The failure to acknowledge the symbolic, and consequently also the meaning, of the sacred.

I have now to conclude on this first movement of my analysis. Deleuze, Brochard, Levinas: their three trajectories, whatever their interest, are unsatisfactory, and, once again, aporetic. In them, the specific regime of the necessity of revelation in Spinoza's philosophy is not brought to light carefully enough, and is assimilated to 1) a confused "cultivation" in which, very strangely, God seems to play no part; 2) the final proof of the personality of God - by which God ceases to be the void and amorphous name of the necessity of nature so as to become a "benevolent will"; and, 3) the evidence of a misunderstanding or misperception of the self-regulative structure and essence of the Bible.

Even if such trajectories aim at making the coherence, cohesion and unity of Spinoza's philosophy manifest (should it be at the price of a "betrayal"), they paradoxically and inevitably lead their reader to conclude that a major discrepancy, if not a contradiction, exists between the Ethics and the Theological-Political Treatise.

\section{Spinoza's Scriptural Hermeneutics: Between Immanence and Transcendence}


Challenging such readings, I would like to affirm that another understanding of Spinoza's conception of revelation is possible, which discloses the symbolic dimension of necessity. In order to do so, I now have to explicitly turn to Spinoza's hermeneutical method. Interpretation of Scripture, in Spinoza, is certainly not a way of bringing some order into the confused and heterogeneous amount of "signs" ("only varying 'signs,' extrinsic denominations that guarantee some divine commandment" (EP 47) as Deleuze states!) that would passively and immediately accompany revelation. It is not a way to acknowledge the presence of a commanding God either ("we see in the end that God, in Spinoza, appears to be a will and a power. His predominant contention is that it is necessary to explain everything according to God's power [puissance divine]," as Brochard states!). ${ }^{12}$ Lastly, it is not a simple artefact aiming at discovering, beyond signs, a "meaning [...] from the outset [...] already fully itself, reified in the text and almost fitted within it before all historical development and all hermeneutics" ( $B V$ 172) (as Levinas states!). Once again, these interpretations end in obscuring the link between the God of the Ethics and the God of the Treatise, which is also the link between philosophy and revelation.

Let's state it clearly: For Spinoza, it was in the nature of God to reveal himself. Again, we are not to ignore the passages where Spinoza affirms the human incapacity to understand the natural possibility of revelation. In Chapter 1 of the Treatise, for example, he declares: "As to the particular law of Nature involved in revelation, I confess my ignorance. I might, indeed, have followed others in saying that it happened through the power of God, but this would be mere quibbling: it would be the same as trying to explain the specific reality of a particular thing by means of some transcendental term. For everything takes place through the power of God. Indeed, since Nature's power I nothing but the power of God, it is beyond doubt that ignorance of natural causes is the measure of our ignorance of the power of God. So it is folly to have recourse to the power of God when we do not know not the natural cause of some phenomenon - that is when we do not know the power of God. However, there is no need anyway for us now to have an understanding of the cause of prophetic knowledge. As I have already indicated, our enquiry is here confined to the teaching of Scripture, with view to drawing our own conclusions from these, as from data presented by Nature. The causes of these Scriptural teachings are not our concern" (TTP 19-20).

How are we to exactly understand such a passage though ? Is Spinoza really stating that we should forget about the origin of revelation (it is "not our concern") ? Or does this passage demand something else, like trying to grasp the origin of revelation as the very source 
of the conflation between the ideal and the symbolic, that is, between truth and meaning within necessity itself?

We should not be too quick in stating that Spinoza's only preoccupation in the Treatise is to establish a strict boundary between faith and philosophy, as if they did not share anything at all. The task of clearly marking the separation between faith and philosophy certainly is "the main object of the whole work." It is true that Scripture's salient message is not metaphysical, but moral, and that interpreting the Scripture does not require philosophical reasoning. "Therefore all knowledge of Scripture must then be sought from Scripture alone" (TTP 88). We perfectly know all this. Yet we cannot be but struck by the way in which the hermeneutical, critical method acts as both a barrier and a bridge between rationality (the method is the work of natural light) and fiction, that is the reservation of images, signs, fantasies that characterize the reception of revelation. What if there was a kind of communication between them? What if philosophy and revelation, the rigour of ideality and the prophetic seeing, expression and exaggeration, and, to a certain extent, philosophical thinking and superstition, originally touched each other?

Such is the risky path I would like to follow in the end in order to explore the aforementioned space between immanence and transcendence in Spinoza. I will explore the status of the sacred as it appears through the hermeneutical inquiry, and results from a critical approach to language in general and to Hebrew language in particular. This will lead me to address the central issue of signification.

\section{The problem of Hebrew language}

Spinoza's refusal to consider the Hebrews as the elected people is intimately connected with the lack of any hermeneutical self-regulation of the Sripture, that is of any automatic universal dimension of the singular. For Levinas, the universality of Judaism is on the contrary essentially founded on a singularity: precisely that of election or chosedness. The universal is always given through a particularity. He writes: "The idea of a chosen people must not be taken as a sign of pride. It does not involve being aware of exceptional rights, but of exceptional duties. It is the prerogative of a moral consciousness itself. It knows itself as the centre of the world and for it the world is not homogeneous: for I am always alone in being able to answer the call, I am irreplaceable in my assumption of responsibility" ( $D F$ 17677). The paradox in Levinas is that each person is said to have access to the Books, but through election only!

Spinoza on the contrary rejects the idea of election, and clearly affirms the nonexistence of the self-regulating hermeneutical principle according to which, as we saw, each 
person - should we say each Jew? - has a genuine access to the universal meaning of the Scripture. The Hebrews do not constitute, as a people, a privileged singularity. This clearly appears in Chapter III of the Treatise, "Of the Vocation of the Hebrews, and whether the Gift of Prophecy was Pecular to Them," in which Spinoza affirms: "We therefore conclude (since God is equally gracious to all and the Hebrews were chosen only with respect to their social organisation and their government), that the individual Jew, considered alone apart from his social organisation and his government, possesses no gift of God above other men, and there is no difference between him and a Gentile" (TTP 40). Further: "Therefore at the present time there is nothing whatsoever that the Jews can arrogate to themselves above other nations" (TTP 45). For Spinoza, as we can see, the superiority of the Hebrews only pertains to the stability and efficiency of their political constitution. Such a superiority is then purely pragmatic and not "spiritual" at all.

There is of course an intimate link between the theory of the non-election of the Hebrews, and that of the absence of privilege of Hebrew language. For Spinoza, there is no such thing as a linguistic election either. Let's recall the fundamental rules of his hermeneutical historical method as developed in Chapter 7. A "history" of Scripture will consist in treating the Bible as a document and it will contain: an account of the language the books of Scripture were written in, establishing the ordinary use of its terms and possible sources of ambiguity; a thoroughly organized collection of passages on various topics, noting all those which are ambiguous or obscure or seem inconsistent with one another; and an account of the life and mentality of the author of each book, when and for whom he wrote, how the book was preserved, transmitted and accepted as canonical, and how many variant readings there are. All these rules are necessary to the extent that the text of the Bible is made of partial consistencies, different authors, and a mixture of clear and obscure passages.

Let's go back to the first principle: the knowledge of the language in which the books were written. This implies that the knowledge of Hebrew language is in the first place necessary: "Now since all the writers of both of the Old and New Testaments were Hebrews, a study of the Hebrew language must undoubtedly be a prime requisite not only for the understanding of the books of the Old Testament, which were written in that language, but also for the New Testament. For although the latter books were published in other languages, their idiom is Hebraic" (TTP 88). Through the status of Hebrew as both a non-chosen and yet indispensable language, Spinoza will present his concept of signification, and, gradually, his concept of the sacred. 
How to read Hebrew language ? The problem with which Biblical hermeneutics is immediately confronted is the following: the letter of Hebrew language is lost. Spinoza lists all the aspects of this loss in Chapter 7: "Where is [such a knowledge] to be obtained? The men of old who used the Hebrew language have left to posterity no information concerning the basic principles and study of this language. At any rate, we possess nothing at all from them, neither dictionary nor grammar nor textbook on rhetoric" (TTP 94). Further: "Nearly all the words for fruits, birds, fishes have perished with the passage of time, together with numerous other words. Then again, the meaning of many nouns and verbs occurring in the Bible are either completely unknown or subject of dispute" (TTP 94). Spinoza then insists on the ambiguities attached to Hebrew language, the multiple meanings of its words, the difficulty of its grammar, the absence of vowels marks, the impossibility to identify with certainty the authors of the Books (see TTP 94-96).

At that point, Spinoza addresses the question of meaning. We have to suppose that even if the literality of Hebrew is lost, something in the meaning of Hebrew words is incorruptible, and has remained legible and understandable. Otherwise, reading the Scripture would be impossible. We are forced to presuppose such an incorruptibility. This integrity is not that of the letter, but of the spirit, that is, of the meaning of the Scripture, which also constitutes its moral content. Spinoza clearly dissociates the semantic content of the message from its literality.

Is this a way to reintroduce surreptitiously an idea of election of the Hebrew language? Not at all! The case of Hebrew language just allows Spinoza to develop his conception of signification, valid in principle for any other language.

Let's go further in the exploration of what "meaning" means for Spinoza. The striking point is the introduction of a very strange distinction between meaning and truth: "For the point at issue is merely the meaning of texts," Spinoza declares, "not their truth" (TTP 88). This implies that the "spirit" of the text consists in its meaning, not in its truth. The meaning of words is incorruptible (Spinoza declares: "it could never have been to anyone's interest to change the meaning of a word" (TTP 93)), but is not to be confounded with their truth. We then have to admit that the semantic content of a word remains stable without this stability constituting any truth.

What, then is the semantic content if different from the truth? The answer is the following: for Spinoza, the meaning is neither the signifier, the letter, nor the referent, the truth - the thing behind, beyond or outside the word. The meaning pertains to the signified (what Saussure would call a "concept"). The signified is the stable component of a word. 
Such a proposition is perfectly paradoxical: how can a signified have any stability by itself, outside its referent?

Before answering, let us return to Levinas, as this point is crucial for him. In his eyes, it is clear that "the method of procedure taught by Spinoza lacks any appeal to an anticipatory vision of the whole, which spills out over the positivist colligation of texts and is perhaps rooted in an inevitable commitment to a project. Spinoza thinks that a discourse can be understood without the vision of truths enlightening it" and isolates "the fundamental meanings of an experience while practicing an 'epochè' in relation to its truth" ( $D F$ 113). For Levinas, this "epochè" of truth forever ruins hermeneutics. What does interpreting means if truth is suspended? It is at that very moment that we can understand the supposed "betrayal" of Spinoza.

Levinas will demonstrate that, in order to sustain the unsustainability of his hermeneutical theory - according to which, as we saw, there can exist signified without truth - Spinoza has in the end to appeal to a Christian principle. In fact, hermeneutics in not really necessary because God has written the law in men's heart. Spinoza: "Furthermore, in accordance with the saying of the Apostle in 2 Cor., chap. 3 v.3, [men] have within themselves 'the Epistle of Christ, written not with ink, but with the Spirit of God, not on tablets of stone, but in the fleshy tablets of the heart, let them cease to worship the letter and to show so much concern of it." (TTP 148). The "betrayal" lies at the heart of this reference to the Paulinian principle of the interior writing. To the "nothing more than paper and ink" (TTP 147) of Scripture, Spinoza opposes the legibility of the heart.

Spinoza's betrayal cannot consist in the fact that he presents Christianity, and Catholicism in particular, as the "universal religion," or because by Scripture he means both the Old and the New Testament. These positions were perfectly natural and usual at the time, and political and theological censorship let philosophers no other choice anyway. Levinas of course knows it. The betrayal more exactly pertains to the distinction between the signified and the truth, which is impossible in and for Judaism. "As a man of his time, Spinoza," Levinas writes, "must have ignored the true meaning of the Talmud. Between the interiority of the Divine inscribed in the hearts of men and the exteriority of opinion, Spinoza would not have recognized, in history, a work of interiorization" ( $D F$ 117). In fact, the desacralisation (anti-Semitism?) that pertains to the signified/truth distinction leads to a "surreptitious" Christianisation of hermeneutics ( $D F$ 108). The internal inscription infinitely surpasses language, infinitely sublates its own linguistic dimension, infinitely renders hermeneutics ("a 
work of interiorisation") useless. In Spinoza, a preordained inscription substitutes for the selfregulative principle...

\section{Spinoza on sacredness}

Against such a vision, it is now time to expose our reading of the motif of sacredness in Spinoza, as linked with the essential symbolic dimension of his hermeneutics. The statement concerning the incorruptibility of signifiers gains its genuine meaning in Chapter 12, where the philosopher exposes his conception of the sacred. The true reason to suppose that signifiers are stable is at last brought to light. The signifier's stability is ascertained by human usage, that is, by convention only, and not according to referents. "Words acquire a fixed meaning solely from their use" (TTP, 146). Words' incorruptibility is then not linked with an originary purity or authenticity. It lays foundation on conventions. The relationship between the signifier and the signified, and of the signified with the referent are purely contractual. So what is incorruptible is convention. Truth pertains to the referent, and meaning to usage, so that the true meaning has definitively separated itself from the truth of things.

Why not after all? A convention may be as long-lasting as a referent. But Spinoza aims at analysing a certain kind of convention, let's say a case of convention within linguistic conventionality itself. A kind of convention which is fragile and unstable in the midst of conventional stability, and thus contaminates the thesis of incorruptibility itself. The convention(s) regarding the sacred.

For Spinoza, what is sacred is neither language, nor what language talks about. There are no sacred things per se, and words cannot be sacred by themselves either. The way in which the sacred comes to (its) words, is, again, through convention. Sacredness is not eternal and can only be settled through usage. The problem is that Chapter 7 , as we just saw, states that signified are incorruptible thanks to convention and usage. Now, Chapter 12 argues that when it comes to the sacred, the meaning of signified can vanish. "Words acquire a fixed meaning solely from their use," Spinoza writes, "if in accordance to this usage they are so arranged that readers are moved to devotion, then these words will be sacred, and likewise the book containing this arrangements of words. But if these words at a later time fall into disuse so as to become meaningless, or if the book falls into utter neglect, whether from malice or because men no longer feel the need of it, then both words and book will be without value and without sanctity. Lastly, if these words are arranged differently, or if by custom they acquire a meaning contrary to their original meaning, then both words and book will become impure and profane instead of sacred." (TTP 146-147). 
The duet of sacralisation and profanation then seems to introduce versatility and changeability in the supposed incorruptibility of words understood as signified. How are we to understand that point? It is not that Spinoza would have changed his mind, now admitting what he refused a few chapters before: that signified can be deleted, come out of use, like abandoned conventions, and that the value of sacredness linked to some of them is then also doomed to disappear. We have to invert the causal order here. It is when the value of sacredness disappears - because it can disappear and get corrupted - it is when profanation happens, that the words that led to devotion can also get out of use. The sacred introduces a fundamental transience and versatility in the domain of the unchangeable, that is, here, of convention. "A thing is called sacred and divine when its purpose is to foster piety and religion, and it is sacred only for as long as men use it in a religious way; if it is devoted to impious uses, then that which before was sacred will become unclean and profane" (TTP 146). The sacred can become profane because it has no referent and no semantic stability either. In a certain sense, it is a void signified, a floating signified, materialized only by transient signifiers: stones (the tables of the Law), light, fire, a house, a voice, a wind or a breath (ruagh...).

\section{From Hermeneutics to Overinterpretation}

What then, is that which "moves" the reader to "devotion" when they read ? What confers the value of sacredness - that is the symbolic dimension - to words, and makes the signifiers burn like fires, or blow like breaths, or kick like stones? What transforms them into signs? Precisely fantasy, imagination, and all their productions, mysteries, fictions, revelations, all propensities of the mind to overinterpret God by want of a stable signified of the sacred.

In that sense, and such is the thesis I want to defend, the sacred only comes from an experience of overreading and a certain use of language related to that experience. Spinoza declares: "Thus it follows that nothing is sacred or profane or impure in an absolute sense apart from the mind [extra mentem], but only in relation to the mind" (TTP 147). The "mind" (and here, mind means the whole of our faculties) has a natural tendency to overinterpretand such is the origin, the very possibility of the sacred. The sacred is rooted in the capacity of the mind to cope with the absence of any stable referent and signified of sacredness itself. Again, nothing (no thing) is sacred per se, not even the supposed "sacred" language, and no semantic long-lasting content can be conferred to the sacred either. In that domain, conventions quickly change! Such is also the space of the symbolic in Spinoza: the possibility 
of opening a hole, an empty square, in the network of signs and things for the transience and mutability of the sacred.

Such an opening does not contradict natural necessity. Overinterpretation is not, or not only, the product of a human defect, but something caused by God, a dimension of his manifestation. It is something that appears with the fact of this manifestation, that is, with revelation. We of course ignore the "causes" of revelation, but we may suppose that the possibility of overreading is not alien to rationality, to "expression" even!

We can then suggest that imagination, fantasy, etc., are not the faulty versions of a not yet rational mind, trapped within the first kind of knowledge. They are answers to the absence of the signified of the sacred, and perhaps for the absence of signified of God himself. After all, the tendency to overread or overinterpret might be the necessary condition, the very first and primitive one, for the rational acceptance of a God without a name. In that sense, a new reading of the hierarchy between the three kinds of knowledge in Spinoza is possible, which should be undertaken one day. A reading that would allow considering the three forms as intermingled rather than rigidly hierarchized and in a certain sense exclusive from each other.

Now, what exactly is overreading and/or overinterpreting? To overread or overinterpret for Spinoza means to confer a semantic content to a word or a phrase by overdimensioning its (absence of) referent. This overdimensioning is fundamentally both spatial and temporal. Spatial: God is understood as a central power, coming from "above," a "highness" (hence all the superpowers attributed to a God conceived as a legislator: jealousy, arbitrariness, love, etc.). "Above," in Spinoza, is the most acute example of the spatial overreading of the "sacred." It implies an overarching and overlooking position proceeding from a hidden and unreachable power.

Temporal: in its temporal sense, "above" means "before." All prophets, "have seen," "have heard" somebody or something, that were there before, already, waiting to be seen or heard. "Above" and "Before" are the two main structures or patterns of sacralisation (cf. TTP ch. 1 and 2). We recognize, in these two structures, the very economy of superstition.

As Benveniste explains in his remarkable article on "Religion and Superstition," "The formal structure of the word [supertitio] appears to be perfectly clear, but the same cannot be said for the meaning." 13 In a certain sense, "superstition" is also a floating signified! "One fails," Benveniste goes on,

to see how the sense of 'superstition' could emerge from the combination of 'super' and 'stare.' To judge by its form, superstitio ought to be the abstract corresponding to superstes 'surviving". But how can these words be connected for their sense? For 
superstes itself does not mean only 'surviving', but in certain well-attested uses it denotes 'witness'. The same difficulty arises for superstitio in its connection with superstitiosus. If we accept that somehow or other superstitio came to mean 'superstition', how is it that superstitiosus meant not 'superstitious' but 'having prophetic gifts, a seer'?

[...] How does superstes, the adjective from superstare, come to mean 'surviving'? This has to do with the sense of super, which does not solely or properly mean 'above' but 'beyond' [...]; the supercilium is not only 'what is above the eyelash', it protects it by overhanging. The very notion of 'superiority' does not denote simply what is 'above' but something more, some measure of progress over what is 'beneath'. Similarly, superstare means 'to stand beyond', in fact, beyond an event which has destroyed the rest. Death has come upon a family: the superstites exist beyond this event. A man who has passed through danger, or a test, a difficult period, who has survived it, is superstes. [...] This is not the only use of superstes: 'To continue existence beyond' implies not only 'to have survived a misfortune, or death' but also 'to have come through any event whatsoever and to exist beyond this event', that is to have been a 'witness' of it.

We can now see the solution: superstitiosus is the one who is 'endowed with the power of superstitio', that is, 'qui vera praedicat', the seer who speaks of past events as if he had actually been present: the 'divination' in these examples did not refer to the future but to the past. Superstitio is the gift of second sight which enables a person to know the past as if he or she had been present, superstes. This is how superstitiosus denotes the gift of second sight, which is attributed to 'seers', that of being a 'witness' of events at which he has not been present. ${ }^{14}$

We see through this powerfully beautiful analysis how the "above" and "before" are both playing at the heart of superstition. "Superstare" would mean to stand beyond, above (super), an event that has destroyed everything and everyone else (the shock of a revelation for example), thus being a survivor to this event that happened before, and to be able to bear witness to it. Or, in a slightly derived sense, to have a "gift of second sight" and do and speak as if one has been "above" or beyond the "past" event so that one can make it present by "seeing" it.

I certainly won't argue that Spinoza is a defender of superstition (!), but I think that his acerb attacks against it aim at dismantling the constitution of superstition into a means of intellectual and political enslavement to authority, not at condemning it as such. It is when 
superstition gets transformed into a dogma, when the floating signified are illegitimately filled up, when theology uses it to change obedience into servitude, when political power uses it to install censorship, thus forbidding all freedom of speech, that it has to be deconstructed. What has to be deconstructed, then, is the authority (auctoritas) produced by revelation. The very basis of superstition though, that is, to repeat, the tendency to overread, is not bad per se. On the contrary it marks the origin of the symbolic and in that sense it cannot be totally separated from ideality.

Deleuze is then not totally right when he declares: "Superstition is everything that keeps us cut off from our power of action and continually diminishes it" (EP 270), or when he identifies revelation with the "genesis of an illusion" (EP 58).

Coming to Levinas, we may admit that Spinoza has perhaps not insisted on hermeneutics and exegesis as he should have, but what he has shown is that the origin of interpretation resided in overinterpration - a dimension that Levinas never takes into account, and would certainly only have confounded with false prophecy. No need, for Spinoza, to refer to any transcendence of the message. Overinterpretation is in a certain sense immanent to the message. Nevertheless, because it introduces some laxity in the tissue of immanence itself, because of the linguistic as well as ontological void lying at the heart of the sacred, it is better to characterize it, as I said earlier, as that what opens a space within necessity, a space which is neither that of immanence, nor of transcendence.

Insisting on the importance of such a space, which is neither within truth nor outside of it, but around it in a certain sense, like a void aura, I certainly did not intend to contradict the vision of Spinoza as a critique of superstition and religious authorities. I agree with Yovel that "for Spinoza, to clear the mind of transcendent images" is an absolute pre-requisit, that "prior to any positive philosophy of immanence, a critique of [...] religion must be undertaken" ${ }^{2}$. I simply aim at demonstrating that Spinoza also acknowledges overinterpretation - the very basis of both superstition and theological dogmatism - as being a necessary beginning. Such a beginning should not be conceived of as a first imperfect step on the scale of knowledge, but as the opening of the symbolic dimension of God, of its meaning, whatever its truth.

The hermeneutical critical method as developed in Chapter 7 then appears to be the threshold between reason and overreading, as well as the threshold between overreading and superstition when the latter gets solidified in an ideological/ theological alienating power, and

\footnotetext{
${ }^{2}$ Yirmiyahu Yovel, Spinoza and Other Heretics, The adventures of Immanence, Princeton University Press, 1989, 3.
} 
can only foster fear and hatred. The task of the method is to help reconstitute each time the contexts in which things or words have been considered sacred, thus aknowledging that the meaning of the sacred, being precisely always contextual, is fundamentally changeable and instable. Such an instability determines what in the Bible is clear and what is obscure : "I call passages clear or obscure according as their meaning is inferred easily or without difficulty in relation to the context, not according as their truth is perceived easily or the reverse by reason" (TTP 101). The methodological mission is to determine each time the part played by overreading in the Scripture in order to bring to light the everlasting strict meaning of the Law, its minimal kernel, and to ban any supernatural meaning from it. In reverse, the method also teaches us that there can be no eternal meaning of the Law, no immediate meaning of the internally written message, without the prior symbolic overdimensioning of all writings and all signs, which constitutes our first encounter with the Law, a first encounter without which there would be no Law at all. Overreading, then, when critically addressed, is not a force of enslavement, but the opening of truth, its gate.

\section{Conclusion}

Spinoza as we know advocates for freedom of opinion, that is also freedom of overintepretation. Men have to be free to see things and words as they want as long as their personal creed concurs with peace, morality and political stability. Therefore freedom of opinion, in the Treatise, is founded on the fact that "every man is bound to adapt [the religious] dogma to his own way of thinking, and to interpret them accordingly as he feels" (TTP 188). The French text says "according to one's complexion (ingenium)," sometimes also translated as "habitus." Freedom of speech is thus essentially linked to the recognition of the legitimacy of every man's natural tendency to overinterpret or overread, and of the symbolic dimension of these operations. Everyone is sovereign when it comes to religious matters, and no external authority should ever legislate on them. Such is the foundation of democracy, and a proof that ordinary people's faith or approach to God is not reducible to a credulous and idiotic act of devotion.

This does not imply, again, that something like a hermeneutical self-regulative power functions at the heart of overinterpretation and allows superstition to control itself, automatically transforming the exegetical excess into the right understanding of the Law. Again, the symbolic, as rooted in overinterpretation, is for Spinoza forever engaged in its own 
contextualization, and it has no essence outside of it. No one is able to know, by definition, what the "next" context will be - and it is not for philosophy to decide. Philosophy has to remain in its own place - which does not mean, again, that philosophy is not concerned with the symbolic.

This brings me back to Deleuze one last time. Confronting Leibniz and Spinoza on "expression," Deleuze states that the great difference between them is that Leibniz integrates the symbolic to his concept of expression, whereas Spinoza excludes it. Equivocity, shadows, ambiguity are part of Leibnizian expressionism. With Leibniz, Deleuze says, we have "a 'symbolic' philosophy of expression, in which expression is inseparable from signs of its transformations, and from the obscure areas in which it is plunged" (EP 329). This would not be the case for Spinoza, "for what is essential for [him] is to separate the domain of signs, which are always equivocal, from that of expressions, where univocity must be an absolute true. Thus we have seen how the three types of signs (the indicative signs of natural perception, the imperative signs of the moral law and of religious revelation) were rejected as inadequate" (EP 330).

Why the need to castrate Spinoza's expression from its symbols ? Why this idolatry of transparency ? Against such repressive gestures, I affirm that to acknowledge the symbolic dimension of immanence does certainly not destroy it. It essentially makes it breathe. 


\section{Bibliography}

Balibar, Etienne, Spinoza et la politique (Paris: PUF, 1984).

Brochard, Victor, Le Dieu de Spinoza (Paris: Manucius, 2013).

Deleuze, Gilles, Expressionism in Philosophy: Spinoza, trans. Martin Joughin (New York: Zone Books, 1990).

Levinas, Emmanuel, Beyond the Verse, Talmudic Readings and Lectures, trans. Gary D. Mole (Bloomington: Indiana University Press, 1994).

Difficult Freedom: Essays on Judaism, trans. Seàn Hand (Baltimore: Johns Hopkins University Press, 1997).

Spinoza, Benedict de, A Theological-Political Treatise, Gebhard Edition, trans. Samuel Shirley, (Indianapolis/Cambridge: Hackett Publishing Company, $2^{\text {nd }}$ edition, 1998).

Benveniste, Emile, Emile Benveniste, "Religion and Superstition", in Indo-European Language and Society, (Study in General Linguistics), tr. E. Palmer, Miami: University of Miami Press, 1973, Book 6, Chapter 7.

Yovel,Yirmiyahu Spinoza and Other Heretics, The adventures of Immanence, Princeton University Press, 1989. 
${ }^{1}$ Levinas has written three essays on Spinoza. The first two are collected in Difficult Freedom: Essays on Judaism, trans. Seàn Hand (Baltimore: Johns Hopkins University Press, 1997), hereafter abbreviated as DF. They are: "The Spinoza Case" (106-10), and "Have you Reread Baruch?" (111-18). The third can be found in Beyond the Verse: Talmudic Readings and Lectures, trans. Gary D. Mole (Bloomington: Indiana University Press, 1994), hereafter abbreviated as $B V$, and it is titled "Spinoza's Background" (168-73). Levinas also refers to Spinoza sporadically in a number of other writings, but in the present paper I will concentrate primarily on his three published essays on Spinoza in the context of Levinas' discussions of bible hermeneutics in Beyond the Verse and in Difficult Freedom.

${ }^{2}$ Cf. Etienne Balibar, Spinoza et la politique (Paris: PUF, 1984), pp.52-56.

${ }^{3}$ Benedict de Spinoza, A Theological-Political Treatise, tr. R.H.M. Elwes (New York: Dover, 2004).

${ }^{4}$ Victor Brochard, Le Dieu de Spinoza (Paris: Manucius, 2013), 14. All translations from this book are mine.

${ }^{5}$ Brochard, Le Dieu de Spinoza, 19.

${ }^{6}$ Cf. TTP 53: "Hence it came about that [one] imagined God as a ruler, lawgiver, king, merciful, just and so forth; whereas these are all merely attributes of human nature, and not at all applicable to the divine nature." On this point, see also the Appendix to Ethics, book 1.

${ }^{7}$ In Chapter 4 for example, Spinoza uses the term "accommodation" ("adaptation" in French).

${ }^{8}$ Brochard, Le Dieu de Spinoza, 21.

${ }^{9}$ Brochard, Le Dieu de Spinoza, 35-36.

${ }^{10}$ Such a hypothesis is twice repeated in Levinas. 1) "The Spinoza Case": "Spinoza, in his Jewish studies, perhaps only had teachers of little calibre.", p. 109; 2) "Spinoza's Background" in Beyond the Verse, p.169.

${ }^{11}$ On the difficult problem of the relationship between the learned readings of the Thora (pardes) and the "personal" ones, see in particular "On the Jewish Reading of the Scripture", in $B V 101-15$.

${ }^{12}$ Brochard, Le Dieu de Spinoza, 98.

${ }^{13}$ Emile Benveniste, "Religion and Superstition", in Indo-European Language and Society, (Study in General Linguistics), tr. E. Palmer, Miami: University of Miami Press, 1973, Book 6, Chapter 7.

${ }^{14}$. Ibid. 